\title{
CONSTITUIÇÃO E SERVIÇO NACIONAL DE SAÚDE
}

\author{
JORGE REIS NOVAIS*
}

RESUMO: Este artigo descreve a delimitação jurídica dada pelo Tribunal Constitucional português, especialmente no que tange à gratuidade, ao Serviço Nacional de Saúde daquele País, como instituição constitucionalmente prevista que representa a principal manifestação da concretização pelo Estado português do direito fundamental à saúde. PALAVRAS-CHAVE: Direito à Saúde. Gratuidade. Tribunal Constitucional. Portugal.

\begin{abstract}
This article describes the legal outline given by the Portuguese Constitutional Court, especially on the gratuity matter, to that country's National Health Service as the constitutionally established institution which represents the Portuguese State's main manifestation of the fundamental right to health's realization.

KEYWORDS: Right to Health. Gratuity. Constitutional Court. Portugal.

SUMÁRIO: I. O Serviço Nacional de Saúde como imposição constitucional; II. A Constituição, o Tribunal Constitucional e o SNS; 1. A existência do SNS e a sua universalidade; 2. Gratuitidade e financiamento do SNS; 2.1. SNS "gratuito" e taxas moderadoras; 2.2. De um SNS "gratuito" a um SNS “tendencialmente gratuito"; 2.3. Um sentido constitucionalmente adequado de tendencial gratuitidade; III. Estado Social e Financiamento do SNS; 1 . Tendencial gratuitidade do SNS e taxas moderadoras; 2. Tendencial gratuitidade do SNS e co-pagamento das prestações; Referências.
\end{abstract}

SUMMARY: I. The National Health Service as Constitutional imposition; II. The Constitution, the Constitutional Court and the NHS; 1 . The NHS' existence and its universality of access; 2. Gratuity and NHS financing; 2.1. "Free" NHS and moderating taxes; 2.2. From a "free" NHS to a "tending towards free" NHS; 2.3. A constitutionally adequate sense to tending towards gratuity; III. Social State and NHS Financing; 1 . NHS' tending towards gratuity and moderating taxes; 2. NHS' gratuity and co-payment of health services; References.

\section{O SERVIÇO NACIONAL DE SAÚDE COMO IMPOSIÇÃO} CONSTITUCIONAL

A primeira nota juridicamente relevante a assinalar na relação entre Constituição e SNS é a de que a existência de um serviço nacional de saúde, com um determinado conjunto de características previamente fixadas (universalidade, generalidade e tendencial

Artigo recebido em 11.02.2010 - Cota de Convite.

Aprovado para publicação pelo Conselho Editorial em 07.07.2010.

Professor da Faculdade de Direito de Lisboa e Professor convidado da Faculdade de Direito da Universidade Nova de Lisboa. Portugal. 
gratuitidade), não é algo que esteja à mercê da livre decisão política do Governo democrático, mas antes algo que reveste a natureza de uma imposição constitucional e que, portanto, independentemente de qual seja a opinião política das maiorias conjunturalmente no poder, tem a sua subsistência juridicamente protegida com o carácter reforçado que a Constituição lhe empresta.

A nossa Constituição, como muitas da sua época, é uma Constituição típica de Estado social e democrático de Direito que, para além dos clássicos direitos de liberdade, contém um vasto elenco de direitos sociais que impõe à observância dos titulares do poder público na qualidade de verdadeiros direitos fundamentais. Isso significa que o conjunto de prestações sociais que o legislador democrático cria na perspectiva da realização desses direitos constitui, em grande medida, a concretização de deveres constitucionais e não uma qualquer benesse de que as maiorias conjunturais disponham e que possam livremente atribuir ou retirar aos cidadãos.

O direito fundamental à saúde ou à protecção da saúde, consagrado no art. $64^{\circ}$ da Constituição, é um desses direitos sociais e o SNS, de instituição prevista no mesmo artigo, constitui a concretização do principal dever do Estado orientado à realização daquele direito fundamental.

Como acontece relativamente a qualquer direito fundamental constitucionalmente acolhido, o Estado tem então, face ao direito à protecção da saúde, e a partir da sua simples consagração constitucional, um dever de respeitar o acesso individual ao bem protegido (obrigação estatal de não afectar a saúde nem as condições e capacidades de acesso próprias de cada particular, bem como de eliminar eventuais impedimentos a um acesso livre), um dever de proteger (contra agressões ou ameaças de outros particulares ou de uma prestação deficiente dos respectivos cuidados de saúde) e um dever de promover condições optimizadas de acesso (melhorando as possibilidades existentes, criando, instituições e serviços, garantindo prestações que, por si próprios, os indivíduos não teriam condições de assegurar).

No entanto, se estes deveres de respeitar, de proteger e de promover são deveres de carácter genérico que se retiram de qualquer norma de direitos fundamentais, e relativamente aos quais os decisores políticos têm, por força da sua relativa indeterminação, uma significativa margem de escolha, de opção política e de definição de prioridades, há outros deveres de conteúdo mais especificamente previsto e de contornos mais determinadamente fixados na Constituição. Relativamente ao direito à protecção da saúde é esse o caso do SNS, uma vez que a Constituição, após consagrar o direito, estabelece no art. $64^{\circ}, n^{\circ} 2$, alínea a), que o direito à protecção da saúde é, entre outras acções, realizado "através de um serviço nacional de saúde universal e geral e, tendo em conta as condições económicas e sociais dos cidadãos, tendencialmente gratuito”.

Portanto, a partir desta decisão do legislador constituinte, não apenas a existência de um SNS, mas também as suas características de universalidade, generalidade e de tendencial gratuitidade adquirem juridicidade reforçada, no sentido de que se impõem soberanamente aos poderes constituídos, independentemente dos respectivos programas, opções e preferências políticas. O SNS, e a sua existência com determinadas características, passou a ser uma imposição constitucional, pelo que, em termos jurídicos, a actuação dos vários poderes públicos neste domínio passa a ser limitada, avaliada e sindicada em 
função da respectiva conformidade aos parâmetros constitucionais. Neste sentido, e uma vez que é o Tribunal Constitucional o órgão encarregado entre nós de garantir, em última instância, a constitucionalidade da actuação dos poderes públicos, passa a ser decisivo para o presente e o futuro do SNS aquilo que o Tribunal Constitucional diga que ele é e que deva ser.

\section{A CONSTITUIÇÃO, O TRIBUNAL CONSTITUCIONAL E O SNS}

De resto, em várias ocasiões ao longo destes trinta anos, o Tribunal Constitucional tem sido, precisamente, chamado a verificar a compatibilidade e conformidade constitucional de algumas opções do legislador e da administração, tomando como padrão de controlo o sentido normativo daquelas imposições constitucionais ${ }^{1}$.

Sem pretensões de exaustão da matéria, o objectivo do presente texto será o de confrontar, neste domínio, alguns dos limites jurídico-constitucionais do SNS que continuam a apresentar maior actualidade e sentido controverso, designadamente os relacionados com as exigências de universalidade, generalidade, mas, sobretudo, de tendencial gratuitidade ${ }^{2}$. Sendo certo que, em termos teóricos, a questão da própria existência de um serviço nacional de saúde e da sua universalidade e generalidade merecem atenção e foram já objecto da intervenção do Tribunal Constitucional, são sobretudo as questões relacionadas com o financiamento do SNS e, portanto, mais directamente ligadas à característica da sua "tendencial gratuitidade”, que revestem maior actualidade e são objecto de interesse renovado. Por isso, elas concentrarão, também aqui, o essencial da nossa atenção.

\section{A existência do SNS e a sua universalidade}

Quanto à necessidade constitucional de existência do SNS, o Tribunal Constitucional teve em 1984 a intervenção decisiva. No Acórdão nº 39/84, o Tribunal Constitucional considerou inconstitucional o diploma que pretendia revogar parte substancial da lei que havia instituído o Serviço Nacional de Saúde, considerando que, tratando-se de uma imposição constitucional precisa e determinada, o legislador ordinário não tinha margem de revogação ou retrocesso, já que se aquela intenção política revogatória fosse bem sucedida ela se traduziria num incumprimento omissivo inconstitucional dos comandos da Constituição. Esta decisão foi, na altura, bastante controversa, sobretudo porque nela assomava a ideia de proibição de retrocesso social, mas a distinção a que o Tribunal procedeu entre normas programáticas e normas de direitos sociais que impõem actuações precisas aos poderes públicos revelou-se da maior importância.

Por sua vez, o sentido a atribuir à imposição constitucional de universalidade e de generalidade do SNS é relativamente pacífico e consensual. Como o próprio Tribunal Constitucional tem afirmado, seguindo, de resto, doutrina consolidada ${ }^{3}$, universal

${ }^{1}$ Sobre a jurisprudência constitucional neste domínio, cf., por último, LUÍS MENESES DO VALE, “A jurisprudência do Tribunal Constitucional sobre o acesso às prestações concretizadoras do direito à protecção da saúde: alguns momentos fundamentais” in Jurisprudência Constitucional, 12, 2006, págs. 12 e segs. ${ }^{2}$ Não consideramos aqui, por mais pacífico, o tema da gestão necessariamente descentralizada e participada do SNS (art. $64^{\circ}, \mathrm{n}^{\circ} 4$ ).

3 Cf. JORGE MIRANDA/RUI MEDEIROS, Constituição Portuguesa Anotada, I, Coimbra, 2005, págs. 654 e seg.; GOMES CANOTILHO/VITAL MOREIRA, Constituição da República Portuguesa Anotada, 3. ed., Coimbra, 2007, pág. 342 e seg. 
significa ser dirigido à generalidade dos cidadãos, conferindo a todos o direito de recorrer ao SNS, mas não impedindo, naturalmente, a existência e a possibilidade de recurso aos serviços particulares de saúde ${ }^{4}$. Por sua vez, geral significa abranger todos os serviços públicos de saúde e todos os domínios e prestações médicos, traduzindo a necessidade de integração ou de garantia de prestação de todos os serviços e cuidados de saúde.

Assim, como estas características de universalidade e generalidade se mantêm inalteradas na norma constitucional desde 1976, não é possível, sem prévia e, ainda assim, muito discutível, revisão constitucional, condicionar ou excluir o acesso ao SNS de categorias particulares de cidadãos ou dele afastar prestações ou cuidados médicos necessários à protecção da saúde. A observância da norma constitucional, independentemente da concepção que se defenda acerca da universalidade dos direitos sociais ${ }^{5}$, exige perspectiva exactamente inversa, isto é, de sentido inclusivo e progressivamente inclusivo, seja no plano da universalidade, seja no da generalidade.

É certo que a possibilidade de admitir a saída dos beneficiários do SNS para outros subsistemas de saúde ou para seguros, de natureza privada ou pública, a título voluntário ou compulsivamente imposto pelo Estado, com contrapartidas traduzidas em expectativas de uma melhor prestação de cuidados de saúde e/ou de benefícios fiscais compensadores, pode vir eventualmente a colocar-se em termos de possível opção política de racionalização do sistema nacional de saúde.

Essa possibilidade coloca, no entanto, dúvidas jurídico-constitucionais relacionadas, não apenas com a actual natureza universal do SNS, mas também com a garantia constitucional do direito à protecção da saúde de todos os cidadãos. Assim, a eventual imposição estatal de saída do SNS não seria constitucionalmente conforme

\footnotetext{
${ }^{4}$ Recente jurisprudência constitucional indirectamente relacionada com a natureza universal do SNS não põe em causa aquele sentido, ainda que possa, por ser aparentemente contrária entre si, suscitar dúvidas sobre o alcance concreto da universalidade. Assim, a propósito da exigência legal de apresentação de cartão de utente, ou de prova da sua requisição, nos dez dias seguintes à prestação de cuidados de saúde, como condição de acesso, sem pagamento, ao SNS, o Tribunal Constitucional, no Acórdão n 67/07, considerou tal imposição inconstitucional, mas, posteriormente, nos Acórdãos $n^{\text {os }}$ 512/08, em fiscalização concreta, e 221/09, em fiscalização abstracta, não considerou as normas legais em causa inconstitucionais. ${ }^{5}$ Cf. diferentes concepções da universalidade — direitos sociais como direitos de todos ou direitos sociais como direitos só dos que precisam - em JORGE MIRANDA, "Pensões no sector bancário e direito à segurança social (parecer)” in Jurisprudência Constitucional, 7, pág. 8 e seg.; VIEIRA DE ANDRADE, “O ‘direito ao mínimo de existência condigna’ como direito fundamental a prestações estaduais positivas —uma decisão singular do Tribunal Constitucional” in Jurisprudência Constitucional, 1, pág. 26.

Da nossa parte, entendemos que os direitos sociais são direitos de todos (a criança que é filho de milionário não tem menos direito à educação ou ao ensino que a criança pobre), mas o que varia são os deveres do Estado de realização desses direitos. Se relativamente ao dever de respeitar o acesso individual aos bens protegidos pelos direitos sociais a posição do Estado é a mesma, já relativamente ao dever de proteger e, sobretudo, ao dever de promover esse acesso individual, as obrigações do Estado variam consoante as diferentes carências e necessidades de ajuda: o Estado deve empenhar-se profundamente na garantia de um acesso gratuito da criança pobre aos diferentes graus de ensino, mas já não necessita de se preocupar em promover análogo acesso ao filho do milionário, uma vez que, por si só, este possui os recursos mais que suficientes para o garantir. Portanto, a titularidade é universal, mas os deveres do Estado, designadamente o dever de promover, são diferenciados.

De qualquer forma, e qualquer que seja a posição que se sustente, no caso do direito à protecção da saúde o espaço de divergência é menor ou praticamente nulo, na medida em que a própria Constituição exige a universalidade do SNS.
} 
sem prévia revisão constitucional e, mesmo com esta, só seria admissível se, por um lado, não pusesse em causa o direito fundamental dos cidadãos, de todos eles —os que saem e os que ficam- à protecção da saúde, e, por outro, se fosse feita de molde a garantir aos cidadãos afectados uma igualdade material de acesso ao mesmo tipo de cuidados e prestações que são garantidos aos beneficiários do SNS.

Por sua vez, na modalidade específica de saída voluntária do SNS, configurando, de alguma forma, uma renúncia ou autolimitação a direito fundamental, ela será, em princípio, menos heteronomamente constrangida, condicionada ou limitada, mas, em contrapartida, só será juridicamente admissível se satisfizer os requisitos constitucionais implicados naquela figura ${ }^{6}$.

Assim, para além de cumprir os mesmos requisitos exigidos para a saída compulsiva, deverá, ainda, assentar num consentimento real do interessado (seja na modalidade de consentimento expresso no caso da saída individual e contratação particular de seguro privado, seja na modalidade de consentimento implicitamente manifestado através da adesão ou integração voluntária numa comunidade ou organização abrangidas por um subsistema ou seguro de saúde) e deverá ser sempre reversível.

De qualquer das formas, estas possibilidades, se bem que susceptíveis de virem a ser chamadas à colação numa discussão política geral sobre as formas de superação dos actuais constrangimentos financeiros do SNS, não se revestem de uma actualidade tão premente quanto aquela que, com origem e motivação próxima nesses mesmos constrangimentos, põe em causa a outra característica fundamental do SNS, ou seja, a respeitante à imposição constitucional de tendencial gratuitidade.

\section{Gratuitidade e financiamento do SNS}

De facto, desde a sua origem, a questão da gratuitidade do SNS nunca foi, como se verá, juridicamente pacífica e é também sobre ela que hoje recaem as maiores dúvidas quando, tendo em conta as actuais dificuldades de financiamento do SNS, se coloca a questão de conhecer o sentido jurídico-constitucional preciso das imposições que, nesse domínio, a Constituição coloca ao legislador ordinário.

Ou seja, partindo do princípio, facilmente verificável, de que existe, entre nós, um problema ou uma dificuldade com o financiamento do SNS, a alternativa política e juridicamente mais controversa que se coloca é a que, questionando a adequação do actual modelo de financiamento, sugere a possibilidade de se passar a exigir, de algum modo, uma contraprestação financeira diferenciada aos utentes do SNS pelos serviços e cuidados de saúde a que recorrem, numa de duas possíveis modalidades: (i) a alteração substancial do actual regime das taxas moderadoras; (ii) a imposição de um co-pagamento das prestações obtidas no SNS pelos beneficiários no momento do consumo.

No entanto, segundo a actual versão da Constituição, o direito à protecção da saúde é realizado "através de um serviço nacional de saúde universal e geral e, tendo em conta as condições económicas e sociais dos cidadãos, tendencialmente gratuito” (art. $64^{\circ}, n^{\circ} 2$, alínea a). Tudo residirá, portanto, em saber se a exigência de pagamentos

${ }^{6}$ Cf. JORGE REIS NOVAIS, Direitos Fundamentais: Trunfos contra a Maioria, Coimbra, 2006, págs. 211 e segs., maxime, 249 e segs. 
diferenciados aos utentes do SNS, em qualquer uma daquelas duas modalidades, é ou não compatível com estes limites constitucionais de universalidade, de generalidade, mas, sobretudo, de tendencial gratuitidade.

\subsection{SNS “gratuito" e taxas moderadoras}

Na sua versão originária, a Constituição era mais impositiva e, aparentemente, inequívoca, já que configurava o Serviço Nacional de Saúde como devendo ser “universal, geral e gratuito”. Colocava-se, então, o problema jurídico da discutível compatibilização dessa exigência constitucional de gratuitidade, plena, com a existência de comparticipações que já eram anteriormente pagas pelos utentes e depois lhes passaram a ser exigidas no quadro da habilitação concedida pelo art. $7^{\circ}$ da Lei do SNS (Lei $n^{\circ}$ 56/79, de 15 de Setembro); segundo esta última norma, “o acesso ao SNS é gratuito, sem prejuízo do estabelecimento de taxas moderadoras diversificadas tendentes a racionalizar a utilização das prestações”.

Tínhamos, portanto, na altura, um problema jurídico-constitucional derivado do facto de, não obstante a Constituição estabelecer a gratuitidade plena, a lei ordinária ressalvar a existência de pagamento de taxas moderadoras. Colocava-se assim, pela primeira vez, a questão da constitucionalidade da existência de taxas moderadoras no acesso ao SNS.

Este problema obteve uma primeira resposta da jurisprudência constitucional em 1982, no Parecer $n^{\circ}$ 35/82 da antiga Comissão Constitucional, que viria a justificar a admissibilidade das taxas moderadoras recorrendo à teoria da relevância jurídica especial das normas de direitos sociais, segundo a qual estas são de realização progressiva, gradual, diferida no tempo, em função das disponibilidades financeiras e materiais do Estado.

Considerava, aí, a Comissão Constitucional que "a gratuitidade assinalada é de tipo eminentemente programático” e, no mesmo sentido, assumia o parecer da Provedoria de Justiça que caracterizava a regra constitucional como impondo uma "gratuitidade progressiva dos serviços de saúde”. Assim, e de acordo com este entendimento, o pagamento de taxas moderadoras não contrariaria a regra constitucional, já que a gratuitidade constitucionalmente imposta seria uma gratuitidade essencialmente programática e progressiva.

Porém, a fragilidade desta construção tornava-se evidente quando se cotejava a norma constitucional sobre o SNS com outras normas constitucionais sobre direitos sociais, particularmente as referentes ao direito ao ensino, e se verificava que a formulação específica da norma constitucional que impunha a gratuitidade no SNS não estava a ser devidamente valorada pela Comissão Constitucional.

É certo que, em geral, as normas constitucionais sobre direitos sociais apresentam aquelas características de gradualidade, de progressividade, de realização programada e diferida no tempo, mas o legislador constituinte não está impedido, mesmo no domínio da realização dos direitos sociais, de fixar aos poderes constituídos imposições precisas, de realização imediata, não dependentes de avaliações, prognósticos ou ponderações a realizar pelo legislador ordinário. É assim que a Constituição nos apresenta, neste domínio dos direitos sociais, normas de estrutura muito diferenciada. 
Encontramos normas que apontam um fim a atingir, mas deixam ao legislador ordinário uma grande margem de liberdade e conformação na escolha dos meios e na definição dos ritmos, prioridades e graus de realização. Nessa altura, cobra plena aplicação a ideia de gradualidade de realização, de progressividade, de ampla liberdade do legislador no trajecto de concretização do direito social.

Outras normas há em que, para além do fim a atingir, a norma constitucional fixa também o sentido do caminho e a orientação estratégica para o alcançar; é esse, por exemplo, o caso da norma do art. $74^{\circ}$, onde, após se consagrar o direito ao ensino e a garantia de igualdade de oportunidades de acesso e êxito escolar, se dá ao Estado a incumbência de "estabelecer progressivamente a gratuitidade de todos os graus de ensino”. A liberdade de conformação do legislador diminuiu, uma vez que não apenas o fim, mas o sentido da via para o alcançar estão pré-determinadas constitucionalmente: o Estado não fica desde logo obrigado a garantir a gratuitidade de todos os ramos de ensino, mas deve caminhar nesse sentido, deve instituí-la progressivamente.

Por último, há outras normas constitucionais sobre direitos sociais em que a liberdade de conformação do legislador ordinário praticamente desaparece, isto é, a Constituição fixa, desde logo, imposições precisas, inequívocas, de realização não sujeita a juízos de prognose e de ponderação. É, por exemplo, o caso da Norma do $\mathrm{n}^{\circ}$ 2, alinea a), do já referido art. $74^{\circ}$, quando se incumbe o Estado de "assegurar o ensino básico universal, obrigatório e gratuito".

Temos, assim, no mesmo artigo da Constituição (o artigo $74^{\circ}$ ), uma distinção clara entre quais são as obrigações e a margem de que o legislador dispõe quanto ao pagamento dos vários graus de ensino: no caso do ensino básico, o Estado está obrigado a assegurá-lo gratuitamente; já quanto aos restantes graus do ensino, o Estado está obrigado a caminhar progressivamente no sentido da gratuitidade, mas a gratuitidade não é de imposição imediata.

Ora, o citado Parecer $n^{\circ}$ 35/82 da Comissão Constitucional, agora a propósito do direito à protecção da saúde do art. $64^{\circ}$, confundia estas distinções e amalgamava todas as normas constitucionais sobre direitos sociais na mesma nebulosa programática, mesmo quando tal característica não se coaduna com a estrutura da norma em questão.

Obviamente, se a Constituição impõe a criação de um SNS e diz que esse SNS é gratuito, essa gratuitidade não é de realização progressiva nem programática, mas de realização simultânea à própria instituição de um serviço nacional de saúde e dela indissociável. Tratava-se, portanto, de saber se a persistência da obrigatoriedade de pagamento das chamadas taxas moderadoras era compatível com esta imposição de gratuitidade e era notório que, independentemente da bondade política do resultado, a fundamentação encontrada pela Comissão Constitucional —que remetia, pura e simplesmente, para a natureza programática dos direitos sociais— não era satisfatória ${ }^{7}$.

\footnotetext{
${ }^{7}$ Esta insuficiência era perceptível e foi implicitamente reconhecida pelo Tribunal Constitucional, no já referido Acórdão n ${ }^{\circ} 39 / 84$, quando, a propósito do diploma que pretendia revogar parte substancial da lei que havia instituído o Serviço Nacional de Saúde, fundamentou o seu juízo de inconstitucionalidade, precisamente, no carácter de comando constitucional impositivo, preciso, de realização imediata, e não meramente programático, da norma contida no art. $64^{\circ}$ da Constituição, que obrigava o Estado a instituir um SNS universal, geral e gratuito.
} 
Não admira, pois, que o problema viesse a ser recolocado nos anos seguintes, desta vez já ao Tribunal Constitucional, órgão que fora entretanto criado na revisão constitucional de 1982. No Acórdão nº 92/85, o Tribunal ainda “escapou” à análise da questão da eventual inconstitucionalidade material dos despachos que regulavam as taxas moderadoras, optando por considerar esses despachos organicamente inconstitucionais e dispensando-se, por isso, resguardando na apreciação do problema da competência, de apreciar a questão de fundo, mas alguns anos decorridos, no Acórdão $n^{\circ} 330 / 89$, teve que decidir a questão principal. Este último Acórdão tem uma importância decisiva na consideração do problema que analisamos e, por isso, importa que nele nos detenhamos mais demoradamente.

O Tribunal Constitucional não se orienta, neste último aresto, pela linha de argumentação seguida no Parecer $n^{\circ}$ 35/82, atrás criticado, ou seja, parte agora do princípio, embora sem conceder expressamente, que a imposição constitucional de gratuitidade possa ser de realização imediata e é a esta luz que abre uma nova linha de fundamentação. O Tribunal Constitucional vai agora verificar se esta gratuitidade constitucional, mesmo se concebida como sendo de realização imediata, é ou não compatível com o pagamento de taxas moderadoras e, nessa abordagem directa, concluiu pela compatibilidade, portanto, pela não inconstitucionalidade da existência de taxas moderadoras a pagar pelos utentes do SNS.

Vejamos como chega a esse resultado. Para o Tribunal Constitucional, o conceito constitucional de gratuitidade é um conceito "normativo" que perde a determinação absoluta que aparentemente resultaria do seu sentido etimológico; através da consagração constitucional, o conceito adquiriria, no entender do Tribunal Constitucional, "um certo halo de indeterminação" que deveria ser posteriormente esclarecido pelo legislador. Assim, a norma constitucional da gratuitidade não garantiria a dispensa de qualquer pagamento por parte dos utentes como contrapartida para as prestações estaduais de cuidados de saúde, mas garantia apenas "que não terão eles de suportar individualizadamente os custos daquelas prestações, pelo que, isso sim, não lhes há-de poder ser exigida, por cada uma de tais prestações, uma contraprestação destinada directamente a transferir (ainda que só parcialmente) para eles o custo da prestação em causa —uma contraprestação, isto é, que tenha como objectivo o 'pagamento' (o pagamento do 'preço') do serviço prestado —ou, então, tal que (designadamente por força do seu montante) venha a ter praticamente um efeito equivalente (e subverta, desse modo, o que poderá qualificar-se como conteúdo essencial mínimo de qualquer ideia de 'gratuitidade')”.

Daí, concluía o Tribunal, que a imposição de taxas racionalizadoras da utilização dos serviços, de moderação da procura desses serviços, se mantidas dentro do razoável, não era incompatível com a Constituição, mesmo quando a Constituição, como acontecia na versão da altura, impunha expressamente o carácter “gratuito” do SNS.

Assim sendo, e qualquer que seja a opinião que se tenha sobre estas decisões, havia no período anterior à revisão constitucional de 1989 um resultado consolidado na jurisprudência constitucional: o da não incompatibilidade entre a imposição constitucional de gratuitidade do SNS e a obrigação legal de pagamento de taxas moderadoras por parte dos utentes. 
De facto, apesar da variação de fundamentações a que se recorre -inicialmente o pretenso carácter progressivo ou programático daquela gratuitidade (Parecer $n^{\circ}$ 35/82 da Comissão Constitucional) e, depois, o seu pretenso sentido normativo que seria distinto do sentido comum (Acórdão nº 330/89 do Tribunal Constitucional) o resultado de não inconstitucionalidade mantém-se e estabiliza-se: as taxas moderadoras não são inconstitucionais.

Dir-se-á, em todo o caso, que a nova fundamentação não é mais satisfatória que a primeira, como se evidencia, de resto, nos votos de vencido apostos ao Acórdão 330/89 ${ }^{8}$. Com efeito, não obstante o esforço argumentativo, é dificilmente aceitável que se possa qualificar como gratuito algo por que tem de se pagar; pode pagar-se muito ou pouco, mais ou menos, mas, se para se obter alguma coisa se tem de pagar, qualquer que seja a justificação invocada, então essa coisa pode ser tudo o que se quiser, mas não é seguramente gratuita. Precisamente por isso é que a Constituição distingue: se o ensino básico é gratuito, não há lugar ao pagamento de quaisquer propinas ou taxas; se nos outros graus de ensino se deve estabelecer progressivamente a gratuitidade, então esse pagamento é ainda, de algum modo, possível.

Assim, independentemente da bondade política do resultado a que chegou ${ }^{9}$, o Tribunal Constitucional viu-se forçado, para atingir esse resultado de admissibilidade constitucional das taxas moderadoras, a introduzir distinções artificiosas que, compreensíveis no contexto em que surgiram, são não apenas inaceitáveis, como, se levadas a sério, introduzem distorções interpretativas que podem ter, hoje, consequências nefastas no plano da determinação do sentido do actual quadro constitucional.

Referimo-nos, concretamente, ao pressuposto hermenêutico que sustenta toda a argumentação do Tribunal Constitucional e que é o seguinte: na sua pretensa acepção normativa, o conceito de gratuitidade deixa de ter um sentido objectivo, para passar a depender da intenção e fins que determinaram a fixação de uma contrapartida financeira a pagar pelos utentes. Se a intenção é transferir para o utente parte do preço do custo da prestação de cuidados médicos, então, por mínima que seja essa parte, a prestação não é gratuita e, como tal, seria inconstitucional. Porém, se a intenção é meramente a de dissuadir o utente de um recurso abusivo a tais cuidados, então, mesmo que a quantia a cobrar seja idêntica ou até superior, desde que não desrazoável, a prestação continua a ser gratuita e, enquanto tal, constitucionalmente lícita.

Obviamente, este conceito normativo de gratuitidade não nos parece sufragável: o conceito de gratuitidade tem um sentido objectivo. Se a Constituição acolhe um conceito de utilização comum, o "ser gratuito", então é para lhe garantir o mesmo sentido que preside à sua utilização na vida comum, sob pena de se transformar o Direito Constitucional num conhecimento de tipo esotérico. Se o ensino básico e o SNS são gratuitos, então são gratuitos, não pagamos! Se no ensino superior se deve

\footnotetext{
${ }^{8}$ Cf., nesse Acórdão, os votos de vencido dos Conselheiros Mário de Brito, Martins da Fonseca e Vital Moreira e, na doutrina, o nosso Os Princípios Constitucionais Estruturantes da República Portuguesa, Coimbra, 2004, págs. 316 e seg.

${ }^{9}$ Cf. GOMES CANOTILHO, Tribunal Constitucional, Jurisprudências e Políticas Públicas, Conferência no XX Aniversário do Tribunal Constitucional, Lisboa, 2003.
} 
estabelecer progressivamente a gratuitidade, então, apesar do mesmo clamor, ainda poderá haver, de algum modo, propinas, mas o legislador terá de acabar com elas, a prazo, e caminhar nesse sentido desde já ${ }^{10}$. Podem considerar-se estas opções políticas inconvenientes e as suas consequências nefastas, mas, nessa altura e sob pena de erosão da força normativa da Constituição, só há uma solução: alterar a Norma Constitucional.

\subsection{De um SNS “gratuito” a um SNS “tendencialmente gratuito”}

Bem andou, portanto, o legislador da revisão constitucional de 1989 quando, a braços com o mesmo problema com que se defrontara, na altura, a jurisprudência constitucional, decidiu alterar a norma constitucional do art. $64^{\circ}, n^{\circ} 2$, alínea a). Onde antes se lia na Constituição "através de um serviço nacional de saúde universal, geral e gratuito” passa agora, após 1989, a ler-se: “através de um serviço nacional de saúde universal e geral e, tendo em conta as condições económicas e sociais dos cidadãos, tendencialmente gratuito".

Procuraremos, posteriormente, determinar o alcance desta alteração constitucional a que, no contexto da discussão a que temos vindo a fazer referência, preside uma intenção clara de mudança e que tem um sentido objectivo prenhe de significado. Mas, por ora, vejamos como foi tal alteração recebida pela jurisprudência constitucional.

O problema foi novamente objecto de apreciação aquando da aprovação da nova Lei de Bases da Saúde, a Lei n ${ }^{\circ}$ 48/90, de 24 de Agosto, sobre cuja eventual inconstitucionalidade o Tribunal Constitucional foi, de novo, chamado a pronunciar-se no Acórdão nº 731/95.

Cotejando aquela Lei de Bases com o novo texto constitucional saído da revisão de 1989, na parte que aqui especialmente nos importa, a questão da gratuitidade do SNS, considerou o Tribunal Constitucional, no que é uma conclusão pacífica, que qualquer que seja o sentido da nova fórmula saída da revisão constitucional, ela teve pelo menos o sentido de flexibilizar a anterior fórmula constitucional de gratuitidade. Ora, maior flexibilidade significaria, em nosso entender, ser levado a concluir que, se antes da revisão de 1989 o Tribunal Constitucional já considerava as taxas moderadoras compatíveis com a exigência de gratuitidade e se não se repudia essa jurisprudência, agora, após a revisão, a maior flexibilidade da norma constitucional determinaria o alargamento da margem de conformação anteriormente reconhecida ao legislador ordinário. Logo, o legislador ordinário poderia fazer algo mais que manter as anteriores taxas moderadoras, estaria menos limitado do que estava o legislador antes da revisão de 1989.

Porém, o Tribunal Constitucional, neste Acórdão 731/95, não dá esse passo. De alguma forma revelando um mal estar relativamente à jurisprudência constitucional anterior à revisão constitucional —considerando implicitamente, porventura, que ela se antecipara à própria revisão-, o Tribunal Constitucional mantém, afinal, inalterada a anterior jurisprudência, como se a revisão constitucional de 1989 não introduzisse qualquer alteração de fundo.

${ }^{10}$ Cf. JORGE BACELAR GOUVEIA, “A inconstitucionalidade da lei das propinas” in RFDUL, 1995, págs. 257 e segs.; JORGE REIS NOVAIS, Os Princípios Constitucionais Estruturantes ..., cit., págs. 314 e segs. 
O Tribunal Constitucional reconhece, a nosso ver adequadamente, que quando a Lei de Bases estabelece que o SNS é basicamente financiado pelo Orçamento do Estado dá cumprimento à prescrição constitucional da sua gratuitidade tendencial, considerando, a seguir, que as taxas moderadoras não são inconstitucionais porque, pretendendo-se através delas "apenas a racionalização da utilização do SNS e não o pagamento do 'preço' dos serviços de saúde prestados, nem resultando delas qualquer impedimento ou restrição do acesso dos cidadãos economicamente mais desfavorecidos aos cuidados de saúde...”, então não há inconstitucionalidade.

Esta conclusão será praticamente consensual quanto à não inconstitucionalidade das taxas moderadoras, mas já nos parece bem mais discutível se com ela se pretender restringir todo o alcance da revisão constitucional de 1989 à "constitucionalização” do pagamento de taxas moderadoras, assim esvaziando, afinal, aquela maior flexibilidade de que atrás se falava.

É essa dúvida que a seguir procuramos esclarecer, considerando agora, após este percurso pela jurisprudência constitucional, aquela que deverá ser, em nosso entender, e após a revisão constitucional de 1989, a mais adequada interpretação do sentido dos limites constitucionais à margem de conformação de que o legislador ordinário dispõe na configuração concreta do serviço nacional de saúde.

\subsection{Um sentido constitucionalmente adequado de tendencial gratuitidade}

Como se disse, o sentido a atribuir a "universal e geral” é relativamente pacífico e consensual. Resta, portanto, esclarecer o problema da tendencial gratuitidade.

Em nosso entender, com a revisão constitucional de 1989 muda verdadeiramente a natureza da norma constitucional de garantia do SNS, o art. 64 ${ }^{\circ}, n^{\circ} 2$, alínea a). Onde antes tínhamos uma regra, a regra da gratuitidade, temos agora um princípio, o princípio da tendencial gratuitidade. Não há apenas, como afirmava o Tribunal Constitucional, uma maior flexibilidade — que, de facto, também existe—, mas uma alteração qualitativa decorrente da transformação da estrutura da norma constitucional ${ }^{11}$.

Com efeito, quando a Constituição impunha a gratuitidade, legislador e Administração nada tinham a ponderar: só tinham que dar estrito cumprimento à regra constitucional; não podiam impor aos utentes do SNS o pagamento de qualquer contraprestação financeira como forma de pagamento dos serviços e cuidados de saúde prestados nesse âmbito (vimos já, também, como o Tribunal Constitucional, embora discutivelmente, considerava o pagamento de taxas moderadoras compatível com a regra da gratuitidade).

Com a revisão constitucional de 1989 há, como dissemos, uma alteração substancial: o SNS deve ser tendencialmente gratuito, o que, e desde logo na própria interpretação da norma constitucional, impõe a necessidade de proceder a valorações, ponderações, em ordem à realização daquele comando na maior e mais adequada medida possível e tendo em conta o peso e a importância que tem para os cidadãos o

11 Sobre o sentido e as consequências dogmáticas da distinção hodierna entre regras e princípios, cf. JORGE REIS NOVAIS, As Restrições aos Direitos Fundamentais não Expressamente Autorizadas pela Constituição, Coimbra, 2003, págs. 322 e segs.. 
acesso gratuito aos cuidados e prestações de saúde, mas também o peso e importância das razões e circunstâncias, de ordem fáctica e jurídica, que apontem num sentido oposto, ou seja, no sentido da não realização da gratuitidade de forma imediata, definitiva e absoluta.

Sobre o alcance da alteração então aprovada não é decisivo o que pensaram, disseram ou calaram os Deputados no momento da votação. Cada um deles terá feito a sua própria avaliação e apreciação das consequências práticas da alteração que então aprovaram —e sobre isso há opiniões e interpretações diversas ${ }^{12}$ - mas aquilo que verdadeiramente deve contar, do ponto de vista da interpretação e aplicação da norma constitucional, é o seu sentido objectivo, colhido à luz dos factores relevantes, como sejam: o sentido da revisão no contexto histórico da controvérsia constitucional que então se desenvolvia e, desde logo, no próprio Tribunal Constitucional; a inserção sistemática da norma no conjunto das normas constitucionais sobre direitos sociais e, particularmente, a comparação com os lugares paralelos do texto constitucional que lhe são mais próximos; o sentido actualista da norma, com consideração das circunstâncias fácticas, problemas e dificuldades que presidem à sua aplicação nos dias de hoje e tendo em conta a interpretação que dela tem feito a jurisprudência constitucional e a doutrina.

Suscitadas especificamente a propósito das prestações no âmbito do SNS, as dúvidas de interpretação remetem, no fundo, para o problema genérico da eventual gratuitidade de prestações estatais tendentes à realização dos direitos sociais. Na maior parte dos casos, a nossa Constituição não se refere expressamente ao problema, mas fá-lo a propósito do direito à saúde e do direito ao ensino, tratados, respectivamente, nos artigos $64^{\circ}$ e $74^{\circ}$, pelo que, em primeiro lugar, será em torno da interpretação dessas normas que procuraremos colher o sentido da resposta constitucional ao nosso problema.

Nestes dois casos, a Constituição recorre a três expressões diferentes que, em princípio, se traduzirão noutras tantas soluções para o problema da gratuitidade. De facto, se no mesmo artigo o legislador constituinte opta por formulações diversas e se utiliza expressamente uma revisão constitucional para introduzir uma fórmula inovatória, a essas opções diferenciadas deve ser atribuído algum sentido.

Umas vezes a Constituição impõe a gratuitidade da prestação (é a situação actual do ensino básico e era também a do SNS antes da revisão de 1989, conforme, respectivamente, o que se dispõe no art. $74^{\circ}, \mathrm{n}^{\circ} 2$, alínea a), e o que se dispunha no anterior art. $64^{\circ}, n^{\circ} 2$, alínea a)). Noutra situação, mais precisamente, quando regula a situação dos restantes graus do ensino, a Constituição já não exige a gratuitidade, mas fala apenas em obrigação de o Estado "estabelecer progressivamente a gratuitidade”.

O sentido desta diferença constitucional não é completamente pacífico, mas é possível chegar a algumas conclusões firmes. O ser gratuito implica o não pagamento ou, no mínimo, o não pagamento de um "preço”. Já o comando de estabelecer progressivamente a gratuitidade tem um conteúdo muito diverso: significa que a

12 Vejam-se, a propósito, as ilacções retiradas pelo Grupo Parlamentar do PCP no requerimento de inconstitucionalidade que veio a dar origem ao Acórdão $\mathrm{n}^{\circ}$ 731/95 e a fundamentação de decisão de sentido inverso tirada no mesmo Acórdão. 
gratuitidade, a não existência da obrigatoriedade de um pagamento a cargo do utente, é o objectivo que, a prazo, se visa alcançar e significa também que se está obrigado a caminhar gradual e paulatinamente em direcção desse objectivo.

Essa diferença de sentido tem relevantes consequências práticas. Num domínio em que vigore o comando de estabelecer progressivamente a gratuitidade, como é o do ensino superior, o pagamento de contrapartidas financeiras para a prestação estatal, no caso o pagamento de propinas, não é inconstitucional, ao contrário do que aconteceria se, eventualmente, a norma constitucional impusesse a existência de um ensino superior gratuito.

O tema tem sido, como se sabe, exaustivamente discutido e tratado, seja no plano doutrinário ${ }^{13}$, seja pela jurisprudência constitucional ${ }^{14}$, a propósito do pagamento e valor periodicamente actualizado das propinas e, naturalmente, as posições sustentadas não são uniformes. Porém, o sentido indiscutivelmente maioritário é o de que o comando da progressiva gratuitidade é, não apenas compatível com a manutenção do pagamento de propinas, como, igualmente, com a respectiva actualização em função dos valores da inflação.

Da nossa parte, concordando com essa ideia geral, criticamos a jurisprudência constitucional relativamente a dois pontos ${ }^{15}$. Por um lado, esta lógica de actualização em função da inflação só faz sentido se o termo originário de referência para calcular a taxa actualizada for o valor das propinas à altura da aprovação da norma constitucional que instituiu a gratuitidade progressiva -1976 - e não, como fez condescendentemente o Tribunal Constitucional, o valor que as propinas tinham em 1941. Se em 1976 o legislador constituinte disse que, a partir daí, tinha de haver uma gratuitidade progressiva, então é a partir daí que se deve verificar se o comando está a ser cumprido, e não a partir de $1941^{16}$. Por outro lado, e mais importante, tomar a sério o comando constitucional de estabelecer progressivamente a gratuitidade implica que tenha de se caminhar nesse sentido; não basta satisfazer-se com a não ultrapassagem do patamar máximo de uma actualização calibrada pelos valores da inflação. Ou seja, tomar a sério o comando constitucional significaria que hoje as propinas deveriam ser mais baratas que em 1976 - pelo menos para uma percentagem mais elevada de estudantes beneficiáriose que, daqui a vinte anos, o "preço” a pagar pela frequência do ensino superior deverá ser relativamente mais baixo do que aquele que hoje se pratica. Isto é, o comando constitucional só é respeitado se se estiver a caminhar progressivamente em direcção à gratuitidade; a não ser assim, viola-se a norma constitucional ${ }^{17}$.

${ }^{13}$ Cf. JORGE MIRANDA, Manual de Direito Constitucional, t. IV, Coimbra, 2008, págs. 444 e segs.; JORGE MIRANDA/M. DA GLÓRIA GARCIA, "A lei de financiamento do ensino superior" in RFDUL, 1998, págs. 314 e segs.; GOMES CANOTILHO, anotação ao Acórdão $n^{\circ}$ 148/94, in RLJ, 3841, 3842, págs. 151 e segs.; JORGE BACELAR GOUVEIA, “A inconstitucionalidade da lei das propinas”, cit.

${ }^{14}$ Cf. o Acórdão do Tribunal Constitucional no ${ }^{\circ} 148 / 94$.

${ }^{15}$ Cf. JORGE REIS NOVAIS, Os Princípios Constitucionais Estruturantes da República Portuguesa, Coimbra, 2004, págs. 3314 e segs.

${ }^{16}$ No mesmo sentido, cf., no referido Acórdão no 148/94, os votos de vencido dos Conselheiros Armindo Ribeiro Mendes e Luis Nunes de Almeida.

${ }^{17}$ Não queremos, com isto, pôr em causa a actual política de propinas ou, ao invés, corroborar a justiça do actual sistema constitucional e legal. Podemos, sem reservas, partilhar das críticas de JORGE 
Este aparente excurso é da maior importância para o tema que aqui analisamos, já que, quando o legislador da revisão constitucional de 1989 decidiu alterar a norma constitucional sobre o SNS, podia ter optado, recorrendo às soluções já consagradas na Constituição, por qualquer das soluções disponíveis no texto constitucional —a gratuitidade e a gratuitidade progressiva —, mas não o fez.

Mais rigorosamente, o legislador da revisão constitucional de 1989, de um lado, afastou a imposição constitucional de gratuitidade do SNS que até aí vigorava. Ora, isso tem de ter um significado. Mais ainda, sabendo-se que o entendimento dominante na jurisprudência constitucional era o que sustentava a compatibilidade do pagamento de taxas moderadoras com a natureza gratuita do sistema, alterar a respectiva norma constitucional tem de ter um sentido de adopção de uma concepção mais flexibilizante do que a que se limita à mera admissibilidade dessas taxas, uma vez que essas já eram impostas na prática e eram jurisprudencialmente toleradas, mesmo antes da revisão constitucional.

De outro lado, tendo abandonado a opção da gratuitidade, o legislador da revisão não adoptou a solução da gratuitidade progressiva. Se o tivesse feito, e admitindo que se adere à jurisprudência constitucional sobre esse conceito, tal significaria que passaria a ser admissível a actualização das taxas moderadoras ao ritmo da inflação, mas, à partida, e de acordo com essa jurisprudência, não mais que isso. Porém, o legislador da revisão não adoptou essa solução, ao que terá objectivamente de ser atribuído um significado, tanto mais que essa era, à altura, a alternativa conhecida do texto constitucional.

O legislador da revisão constitucional de 1989 adoptou, inovatoriamente, uma solução diferente, a da tendencial gratuitidade, o que, portanto, será algo distinto, tanto da gratuitidade, como da gratuitidade progressiva. Será, precisamente, esta nuance que não terá sido devidamente tida em conta pelo Acórdão no 731/95 do Tribunal Constitucional, pelo menos se ele for lido no sentido de não permitir outra margem ao legislador ordinário que não seja a consagração de taxas moderadoras, de valor eventualmente actualizado de acordo com os parâmetros da inflação.

Tendencial gratuitidade significa que a prestação de cuidados e serviços de saúde no âmbito do SNS tende a ser gratuita, mas não tem de ser gratuita, pelo menos, não tem de ser sempre gratuita. O ser gratuito será a inclinação natural do SNS, será o seu sentido geral, a tendência, mas não será uma exigência de carácter absoluto, no sentido de vedar, hoje, o pagamento de qualquer "preço" do custo de prestações obtidas no âmbito do SNS. Se já não o era (pelo menos no entendimento do Tribunal Constitucional) quando a Constituição impunha a gratuitidade, muito menos o será, por maioria de razão, agora, quando a Constituição fala em tendencial

MIRANDA/M. DA GLÓRIA GARCIA (“A lei de financiamento do ensino superior”, cit.) à injustiça de um sistema de ensino superior gratuito para todos nas condições de escassez de recursos como é aquela em que vivemos e viveremos. Ponto é que, então, para nós, a ser assim, é necessário alterar em conformidade a norma constitucional. Nesse sentido, não acompanhamos a perspectiva de JORGE MIRANDA, para quem o comando constitucional de estabelecimento progressivo da gratuitidade nos vários graus de ensino significa, aplicado ao ensino superior, a obrigatoriedade de caminhar gradualmente, não no sentido da gratuitidade, mas no sentido da tendencial gratuitidade (cf. Manual..., cit., págs. 446 e seg., nota). 
gratuitidade. A letra da Constituição, o contexto da revisão constitucional de 1989, o sentido da jurisprudência constitucional, a comparação com as opções da Constituição no domínio do ensino, por si só, indiciam esta conclusão.

Sob diferentes perspectivas, mas convergindo na mesma conclusão, é também esta a posição, parece-nos, de JORGE MIRANDA, para quem, comparando com o que acontece com o financiamento do ensino superior, a gratuitidade só se impõe em função das condições económicas dos utentes ${ }^{18}$. É, ainda, mais claramente, a posição sustentada por SÉRVULO CORREIA (“embora os cuidados de saúde devam ser gratuitos tanto quanto o permita a situação financeira do Estado, não terão de sê-lo absolutamente. E a imputação do dever de efectuar pagamentos em correlação com cuidados prestados e a modulação dos respectivos montantes não deverão ser alheios às condições económicas dos utentes"19) e, também, por RUI MEDEIROS (“em rigor, a letra e a teleologia objectiva do preceito não obstam a que se reconheça que o legislador, com a sua liberdade de conformação, imponha o pagamento dos serviços prestados aos utentes que tenham —num juízo relativo que atenda ao custo dos referidos serviços - suficientes meios económicos"20).

Ora, se na passagem da gratuitidade à tendencial gratuitidade se legitima a existência de situações de não gratuitidade de prestações no âmbito do SNS, isso traduzir-se-á na possibilidade de o legislador ordinário instituir, em certas circunstâncias — que, por ora, deixamos por determinar-, um pagamento, total ou parcelar, do custo das prestações em causa. Tudo residirá, então, em saber qual a margem de que dispõem os poderes constituídos na determinação das circunstâncias em que é legítimo pedir a utentes do SNS um pagamento como contrapartida das prestações e na fixação do correspondente "preço". Isto é, quais os constrangimentos concretos que os limites constitucionais de que falámos no início colocam à margem de escolha e decisão por parte do legislador ordinário.

Como dissemos, esses limites constitucionais são os que decorrem da natureza jusfundamental, na qualidade de direito social, do direito à protecção da saúde e os que são directamente impostos pela cláusula constitucional que impõe ao Estado um dever de realização daquele direito através da instituição “de um serviço nacional de saúde universal e geral e, tendo em conta as condições económicas e sociais dos cidadãos, tendencialmente gratuito”.

\section{ESTADO SOCIAL E FINANCIAMENTO DO SNS}

A nossa Constituição reconhece expressamente o direito à protecção da saúde como direito fundamental. De resto, mesmo que não o fizesse, tal decorreria, naturalmente, da natureza social do nosso Estado de Direito. Esse reconhecimento tem, necessariamente, consequências jurídicas.

Assim, ser direito fundamental constitucionalmente consagrado significa, desde

\footnotetext{
${ }^{18}$ JORGE MIRANDA, Manual..., cit., págs. 444 e segs.

${ }^{19}$ SÉRVULO CORREIA, "As relações jurídicas de prestação de cuidados pelas unidades de saúde do Serviço Nacional de Saúde”, in Direito da Saúde e Bioética, Lisboa, 1996, pág. 43.

${ }^{20}$ Cf. anotação do Autor ao art. $64^{\circ}$ da Constituição in JORGE MIRANDA/RUI MEDEIROS, Constituição Portuguesa Anotada, I, Coimbra, 2005, pág. 657.
} 
logo, que o direito à protecção da saúde deixa de estar na inteira disponibilidade dos poderes constituídos, mesmo quando esses poderes têm uma legitimidade democrática e governam de acordo com o programa político que apresentaram ao eleitorado. É que, em Estado de Direito democrático, a margem de actuação do poder político, incluindo do legislador democrático, está juridicamente delimitada pela necessária observância dos direitos fundamentais. Assim o exige a supremacia jurídica da Constituição formal e o princípio da constitucionalidade das leis e do exercício do poder político.

Portanto, para o problema aqui em análise, este facto tem a maior importância, já que, tratando-se de eventual alteração da regulação legal actualmente em vigor de financiamento do serviço nacional de saúde, essa alteração afecta necessariamente as condições de exercício e realização do direito à protecção da saúde, pelo que só será constitucionalmente legítima se não se traduzir em violação deste direito.

É certo que o direito à protecção da saúde é um direito fundamental de natureza social e tal facto tem igualmente consequências em termos de especificidade do tipo de vínculos que este tipo de direitos fundamentais —os direitos sociais — projectam sobre os poderes constituídos. Ou seja, trata-se de direitos cuja realização é, na sua dimensão principal, intrinsecamente dependente e condicionada pelas disponibilidades materiais e financeiras do Estado, pelo que, estando o Estado obrigado a observar as correspondentes normas constitucionais e a realizar o direito à medida das respectivas disponibilidades, a exigibilidade de algumas prestações estatais por parte dos cidadãos não é directa e imediatamente vinculativa.

Ou seja, se o cidadão pode exigir imediata e directamente do Estado o respeito pelas suas condições e capacidades próprias de acesso ao bem saúde e a protecção desse acesso, já quando está em causa a exigência de ajuda estatal, isto é, de cumprimento do dever estatal de promoção do acesso dos cidadãos aos cuidados de saúde, aí o direito dos cidadãos e os correspondentes deveres estatais estão sujeitos a algumas reservas.

Trata-se, neste último caso, de um encargo estatal de prestações sociais com um custo financeiro sensível, pelo que, numa situação de escassez de recursos, tais direitos se encontram necessariamente sob reserva do possível ou, mais rigorosamente, sob reserva do financeiramente possível, uma vez que dependem essencialmente de uma concretização/conformação legal que compagine as necessidades da respectiva realização com a existência de suficientes recursos financeiros ao alcance do Estado. Isto significa que, consequentemente, se reconhece aos poderes públicos democráticos uma margem de decisão e opção políticas sobre as formas e modalidades mais adequadas ou oportunas de realizar aqueles fins.

Assim, o Estado está obrigado a realizar e concretizar o direito à proteç̧ão da saúde na maior medida possível, tendo em conta as respectivas disponibilidades, mas o particular não pode exigir judicialmente a prestação de todo e qualquer cuidado médico ou de saúde se o Estado puder mobilizar a seu favor aquelas reservas, designadamente se o Estado não dispuser das condições materiais que lhe permitam disponibilizar tal cuidado em igual medida a todos os cidadãos. 
Ora, numa situação de estrutural escassez de meios, cabe, por isso mesmo, ao legislador democrático, designadamente ao legislador que aprova o orçamento, uma relativamente ampla margem de decisão quanto à mais adequada distribuição dos recursos afectos à realização, não apenas do direito à protecção da saúde, mas de todos os outros direitos sociais igualmente consagrados na Constituição.

Neste sentido, a vinculação jurídica que obriga os poderes constituídos no domínio da dimensão principal dos direitos sociais é uma vinculação de algum modo atenuada pelos condicionamentos financeiros que são indissociáveis da especial natureza destes direitos. Os direitos sociais, nesta sua dimensão de prestação positiva, de promoção do acesso, são de realização gradual e diferida no tempo, em função dos recursos materiais, humanos e financeiros que o Estado pode afectar à respectiva realização.

Isso não significa, porém, que os poderes constituídos sejam inteiramente livres nessa actuação de realização progressiva dos direitos sociais. Como se disse, a natureza materialmente jusfundamental e o reconhecimento formalmente constitucional dos direitos sociais significam, por definição, vinculação jurídica, condicionamento e sujeição do Estado relativamente à obrigatoriedade daquela realização.

São diversas as modalidades comummente reconhecidas da relevância jurídica dos direitos sociais ${ }^{21}$, mas, para o problema que aqui nos ocupa, interessa sobretudo a relevância que respeita à eventual garantia jurídica do nível de realização já alcançado. Ou seja, trata-se de saber, no caso, o seguinte: tendo o direito à saúde obtido já um certo estádio de realização, designadamente em termos de acesso gratuito, ou quase gratuito, à generalidade dos cuidados de saúde por parte da generalidade dos cidadãos, será possível ao poder político retroceder no presente grau de realização do direito, instituindo, eventualmente, uma obrigatoriedade de pagamento de custos de prestações de saúde, a exigir dos particulares com suficiente capacidade financeira?

Esta questão foi muito discutida, entre nós, há alguns anos, havendo, na altura, quem sustentasse a pretensa existência de um princípio constitucional, o chamado princípio da proibição do retrocesso ou da não reversibilidade na realização dos direitos sociais, que impediria qualquer diminuição nas possibilidades de acesso ao bem protegido pelo direito social e que o Estado houvesse entretanto garantido. De alguma forma, esta visão perpassa mesmo em alguma jurisprudência do nosso Tribunal Constitucional, como seja no já referido Acórdão nº 39/84 sobre revogação do Serviço Nacional de Saúde ${ }^{22}$.

Porém, à medida que se foi solidificando o entendimento dos direitos sociais como direitos sob reserva do possível e, por outro lado, se difundiu a consciência da crise e das dificuldades estruturais do Estado social europeu, esta ideia da proibição do retrocesso foi sendo abandonada e, hoje, pode considerar-se ultrapassada. Com efeito, se a realização dos direitos sociais depende estruturalmente das disponibilidades financeiras do Estado e se estas podem variar significativamente, não há como sustentar juridicamente uma ideia de pretensa cristalização dos avanços entretanto realizados mesmo em caso de regressão acentuada e constante dos recursos financeiros ao

${ }^{21}$ Cf. JORGE REIS NOVAIS, Direitos Sociais, Coimbra, 2010, págs. 181 e segs. e págs. 302 e segs.

${ }^{22}$ Cf., igualmente neste sentido, LUIS MENESES DO VALE, loc. cit., págs. 20 e seg. 
dispor do Estado. Tudo o que se pode, neste domínio, exigir do Estado é que ele realize os direitos sociais tanto quanto possível; ora, amanhã pode não ser materialmente possível manter o nível das prestações que se garantem hoje, sob pena de ser o próprio Estado social, no seu conjunto, que venha a entrar em colapso e ser decisivamente posto em causa.

Isto não quer dizer, no entanto, que os direitos sociais se convertam em meras proclamações programáticas, sem relevância jurídica e inteiramente à mercê das maiorias no poder. Tal constituiria uma negação do valor desses direitos enquanto direitos fundamentais de nível constitucional. Ser direito fundamental significa, precisamente, que a maioria democrática não dispõe livremente da sua realização, mas está, antes, por ele juridicamente vinculada.

Assim, se é certo que, tal como qualquer outro direito fundamental, também os direitos sociais podem ser afectados, limitados, restringidos, tal só é constitucionalmente admissível quando há um fundamento sério que justifique tal afectação, ou seja, quando haja razões ponderosas e objectivamente comprováveis —que não meras diferenças de opinião política ou preconceitos ideológicos das maiorias conjunturalmente no poder - que sobrelevem a importância das garantias proporcionadas pelo direito social.

Acontece, porém, que no domínio dos direitos sociais, atenta a especial natureza destes direitos, razões suficientemente ponderosas que justifiquem a limitação podem ser, e são frequentemente, razões assentes na escassez de recursos que determinam, ou aconselham, a alteração das normas legais de garantia do direito social num sentido desvantajoso para os particulares. E, se o Estado puder comprovar objectivamente a existência e o peso dessas razões, a margem de controlo que cabe à justiça constitucional reduz-se significativamente, uma vez que, estando em causa a comprovada necessidade de reafectação orçamental dos recursos disponíveis, é essencialmente ao Parlamento, e não ao juiz, que compete decidir.

Ainda assim, a decisão parlamentar continua balizada e vinculada pelos limites constituídos pelo direito fundamental, pelo que, para além da demonstração da preponderância das razões a favor da restrição do direito social, a maioria parlamentar tem necessariamente de observar os princípios estruturantes do Estado de Direito, como sejam, o princípio da igualdade, da protecção da confiança, da proibição do excesso e, se for o caso, da protecção da dignidade da pessoa humana.

Tudo passa, portanto, por verificar de que forma e com que alcance razões de sentido contrário, e igualmente ponderosas, relevam no domínio de que tratamos quando se coloca a eventualidade de instauração de obrigatoriedade de algum co-pagamento de prestações no âmbito do SNS.

Em primeiro lugar, cabe reconhecer a enorme pressão que as presentes dificuldades financeiras colocam sobre a decisão política. Se essas dificuldades apresentam um carácter global, que se projecta indiferenciadamente sobre todos os sectores e sobre a generalidade dos direitos sociais, elas revestem uma particular acuidade no domínio da saúde, onde a nota mais impressiva dos últimos anos é a do crescimento ininterrupto, acentuadamente progressivo e, em geral, não programado, 
das despesas totais e das despesas públicas com a saúde e dos gastos com o serviço nacional de saúde ${ }^{23}$.

Sendo certo que as despesas com a saúde crescem generalizadamente em todos os países, a partir de 2001 os gastos públicos e a despesa total com a saúde em Portugal já ultrapassam a média dos países da União Europeia e da OCDE: a média dos gastos totais com a saúde da UE e da OCDE em percentagem do PIB era de 8,9\% e era, em Portugal, de $9,9 \%^{24}$. De 2,6\% do PIB, em 1970, as despesas com saúde em Portugal passaram para 9,9\% em 2006. Por sua vez, a percentagem da despesa pública na despesa total com a saúde passou de 62,6\%, em 1995, para 70,5\% em 2002, e para 71,5\% em 2006. O peso dos gastos públicos com saúde face ao PIB era na OCDE de 5,1\%, em 1980, passando para 6,4\% em 2004; por sua vez, em Portugal, nesse mesmo período esse peso duplicou: era de 3,6\% em 1980, passou para $7,2 \%$ em $2004^{25}$.

Factores conhecidos, como a generalização da cobertura de cuidados de saúde, o aumento da esperança média de vida, a evolução cultural das populações e uma procura mais exigente de cuidados médicos e o progressivo recurso a meios sofisticados e dispendiosos de diagnóstico traduzem-se, qualquer que seja a avaliação sobre o peso de cada um destes factores isoladamente considerados ${ }^{26}$, numa tendência constante e praticamente irreversível de crescimento da despesa total e dos gastos estatais com a saúde.

Não sendo possível prever a diminuição significativa destes gastos através de ganhos de eficiência, nem a sua cobertura através do simples crescimento previsível da economia, é todo um difícil problema, de resolução premente, de garantia da sustentabilidade do SNS que se coloca actualmente aos responsáveis políticos.

Parece, portanto, que se o poder político puder fazer a demonstração da inevitabilidade de ter de fazer repercutir sobre os cidadãos, de uma ou outra forma, a necessidade de resposta a estas tendências irreversíveis de agravamento dos gastos com a saúde, a eventual escolha política de o fazer através da exigência de pagamento de alguns custos de prestações de saúde por parte dos utentes menos carenciados do SNS (a alternativa seria o aumento generalizado dos impostos) cabe dentro da margem de livre decisão do legislador democrático e, neste contexto, está constitucionalmente justificada ou, pelo menos, não padece de inconstitucionalidade.

Ponto é, como se disse, que tal decisão observe igualmente os princípios constitucionais estruturantes a que atrás se aludiu.

\footnotetext{
${ }^{23}$ Cfr., para além dos relatórios da OCDE (OECD Health Data 2006 in www.oecd.org), as análises e estimativas convergentes de JORGE SIMÕES, Retrato Político da Saúde, Coimbra, 2004, págs. 139 segs.; CORREIA DE CAMPOS/FRANCISCO RAMOS, "Contas e ganhos na saúde em Portugal. Dez anos de percurso” in Desafios para Portugal, Lisboa, 2005, págs. 159 e segs.; PEDRO P. BARROS/PEDRO NUNES,

“A sustentabilidade financeira do Serviço Nacional de Saúde”, dactilografado, Universidade Nova de Lisboa, 2005.

${ }^{24}$ Cf. OECD Health Data 2007.

${ }^{25}$ Cf. JORGE SIMÕES, PEDRO P. BARROS, JOÃO PEREIRA (coords.), A Sustentabilidade Financeira do Serviço Nacional de Saúde, Lisboa, 2008, págs. 68 e segs.

${ }^{26}$ Cfr. PEDRO P. BARROS/PEDRO NUNES, loc. cit.
} 
Desde logo, e atendendo à íntima associação do direito à protecção da saúde com o direito a uma vida condigna e, consequentemente, à extrema relevância daquele direito, tem sempre de ficar garantido um pressuposto reiteradamente assinalado na jurisprudência do Tribunal Constitucional: qualquer decisão neste domínio nunca pode implicar que, por razões estritamente económicas, um qualquer cidadão deixe de ter acesso aos cuidados de saúde de que efectivamente careça.

Este é um ponto de vital importância, cujo reconhecimento permite, por outro lado, concluir pelo carácter quase supérfluo de uma eventual revisão constitucional orientada pelo objectivo que aqui consideramos. Ou seja, reconhecido o carácter intransponível deste limite que o direito à protecção da saúde coloca sempre aos decisores políticos, a revisão constitucional não poderia possibilitar mais do que aquilo que já é actualmente permitido pelas normas constitucionais em vigor, desde que adequadamente compreendidas.

Quando muito, uma revisão constitucional orientada neste sentido apenas tornaria claro e indiscutível aquilo que é já, hoje, a conclusão a retirar do actual quadro constitucional: cabe ao poder político decidir de que forma o crescimento dos gastos com a saúde deve repercutir, directa ou indirectamente, em contraprestações a cargo dos cidadãos, garantido que esteja que ninguém, por razões estritamente económicas, se veja impedido de recorrer aos cuidados de saúde de que necessita no âmbito do SNS.

Como a permanência destes dois limites - livre margem de decisão política do legislador e garantia do acesso de todos aos cuidados de saúde- é estruturalmente exigida no quadro de um Estado de Direito social como o nosso, nem esses limites, nem a natural tensão em que convivem, podem ser significativamente alterados por qualquer revisão constitucional, mesmo que, como seria no caso concreto, se fizesse desaparecer a obrigatoriedade de existência de um SNS tendencialmente gratuito. Uma tal revisão constitucional poderia fazer desaparecer algumas das incertezas que actualmente se suscitam, mas não poderia produzir qualquer alteração qualitativa relativamente ao actual quadro constitucional e, daí, o seu carácter quase supérfluo.

Requisito da maior importância, qualquer que seja a alteração legal produzida, deverá ser, portanto, a sua natureza não excessiva relativamente às necessidades vitais de um acesso não economicamente condicionado aos cuidados de saúde. Nesse sentido, assente essa necessidade de razoabilidade de qualquer alteração legislativa, perde igualmente relevância o tipo de enquadramento legal com que se configure a repercussão dos custos das prestações de saúde sobre os utentes do SNS.

\section{Tendencial Gratuitidade do SNS e taxas moderadoras}

Actualmente, enquanto utentes do SNS, os cidadãos apenas têm de pagar as chamadas taxas moderadoras. Segundo a Base XXXIV da Lei de Bases da Saúde (Lei no 47/90, de 24 de Agosto), "com o objectivo de completar as medidas reguladoras do uso dos serviços de saúde, podem ser cobradas taxas moderadoras", de que "são isentos os grupos populacionais sujeitos a maiores riscos e os financeiramente mais desfavorecidos".

Consagrou-se, assim, a lógica, conhecida e já analisada, de que os utentes do SNS não pagam uma retribuição, ainda que parcelar, das prestações, mas apenas lhes 
é exigida uma importância uniformemente estabelecida, e de que estão isentos os mais carenciados ou os que se encontrem em situação de especial debilidade ou risco. O pagamento dessa importância a título de taxa moderadora tem como objectivos proclamados uma racionalização de funcionamento do SNS, na medida em que funcione, no lado da procura de cuidados de saúde, de forma dissuasora de um acesso abusivo e injustificado ao SNS.

A alteração do actual regime das taxas moderadoras pode, então, configurar-se através de duas vias: a generalização ou, pelo menos, o alargamento de aplicação de taxas moderadoras a serviços ou prestações que actualmente não estão sujeitos a qualquer pagamento e o aumento do montante das taxas moderadoras com um alcance diferente do que resultaria da sua simples actualização em função dos valores da inflação.

Até hoje, os decretos-leis de desenvolvimento da Lei de Bases da Saúde têm-se limitado, quando regulam a fixação das taxas moderadoras, a dividir os utentes do SNS em dois grandes grupos: os isentos e os não isentos do respectivo pagamento. Nada obriga, porém, a que assim seja. De facto, a própria vinculação da existência de taxas moderadoras ao fim de moderação da procura dos consumos remete para a possibilidade ou para a necessidade de diferenciação do montante das taxas moderadoras em função do rendimento e disponibilidades dos beneficiários.

A Constituição não apenas admite, como incentiva a diferenciação em função das condições económicas e sociais dos utentes. Por sua vez, a Lei de Bases não introduz qualquer limitação a esse propósito. Ora, inerente à lógica de racionalização e dissuasão do recurso injustificado aos cuidados de saúde prestados no âmbito do SNS está a ideia de que as taxas moderadoras possam cumprir com efectividade esses objectivos e resulta evidente que uma obrigatoriedade de pagamento uniforme de taxas moderadoras, indiferente ao nível de rendimento do utente, não cumpre adequadamente esses fins. Uma taxa moderadora de um montante fixo pode dissuadir um utente de menores rendimentos, mas já não cumprirá qualquer efeito dissuasor e, logo, racionalizador, relativamente a um utente de rendimentos substancialmente mais elevados.

Efectivamente, se as taxas moderadoras se justificam no proclamado objectivo de racionalização de funcionamento do SNS através da dissuasão de um acesso abusivo e injustificado às suas prestações, então é óbvio que, para alcançarem com eficácia esse objectivo, o seu montante pode atender à situação económica real dos utentes - aquilo que para um utente é um montante dissuasor, para outro pode ser absolutamente irrelevante-, pelo que as taxas moderadoras podem ser diferenciadas em função das condições económicas e sociais dos utentes desde que tal não corresponda a um aumento excessivo, seja fundamentável na necessidade de alcançar uma moderação efectiva da procura de cuidados de saúde, e seja apto, necessário e adequado a alcançar esse fim.

Já a outra possibilidade —a criação de novas taxas moderadoras- pode revestir-se de maior complexidade. Ou seja, elas só nos parecem admissíveis, na lógica atrás desenvolvida, se puderem ser um meio idóneo, necessário e adequado a moderar ou prevenir os consumos excessivos e abusivos de cuidados médicos e prestações garantidos pelo SNS. 
Se não for esse o caso, seja pelo seu montante, seja porque se aplicam à procura de cuidados ou de prestações independentes da vontade do utente, no sentido de situações de doença que o forçam à procura impreterível dos referidos cuidados e prestações, então não deve haver lugar à aplicação de taxas de moderação, na medida em que a respectiva imposição de pagamento seria falha da racionalidade que a justifica.

Enquanto taxa moderadora, uma tal imposição de pagamento seria inapta a atingir o fim de moderação de consumo — no caso em que o problema de saúde do utente não lhe deixe outra alternativa que não seja a procura dos cuidados médicosou seria inadequada e desrazoável, na medida em que não faz sentido que o Estado imponha, com fins exclusivos de moderação da procura, um sacrifício por consumos cuja estrita necessidade os coloca fora do controlo e da disponibilidade do utente. Como é óbvio, qualquer imposição de um pagamento produz sempre algum efeito, maior ou menor, inibidor do consumo. Mas, para o que aqui importa, o sacrifício imposto não seria adequado e, como tal, não seria juridicamente admissível, se o Estado o impusesse ao abrigo de uma justificação — a moderação do consumo — que, aqui, não seria aceitável.

Isto não quer dizer que a exigência de um pagamento por parte do utente seja, nessa circunstâncias, inadmissível; trataremos dessa questão a seguir. O que esse pagamento não poderá é ser exigido a título de taxa moderadora, pelo menos sem que haja uma prévia reconfiguração legal do sentido destas taxas. De facto, na nossa ordem jurídica as taxas moderadoras têm uma configuração que exclui a sua aplicação nessas circunstâncias. É certo que a Lei de Bases da Saúde (Lei n 48/90, de 24 de Agosto) não é suficientemente explícita a propósito, uma vez que as define apenas através da justificação da sua possibilidade de aplicação "com o objectivo de completar as medidas reguladoras do uso dos serviços de saúde” (Base XXXIV, $\mathrm{n}^{\circ}$ 1). Porém, seja numa jurisprudência constitucional firme e reiterada, seja nos decretos-lei de desenvolvimento, às taxas moderadoras tem sido atribuída, de forma consolidada, a configuração que aqui pressupomos.

\section{Tendencial gratuitidade do SNS e co-pagamento das prestações}

A outra modalidade, também juridicamente possível, como vimos, no actual quadro constitucional, mas politicamente mais controvertida, será a assunção da necessidade de passar a exigir aos utentes do SNS com suficientes recursos o pagamento, pelo menos parcelar, dos custos de prestações que obtêm no âmbito do SNS, eventualmente combinado com o pagamento das taxas moderadoras.

Curiosamente, se bem que o legislador ordinário se tenha mantido estritamente nos quadros da lógica do pagamento de taxas moderadoras, ensaiou em diferentes ocasiões, pelo menos no plano discursivo, a transição para uma lógica de combinação das taxas moderadoras com o pagamento dos custos de prestações por parte dos utentes.

Assim, no proémio do Decreto-Lei $n^{\circ}$ 54/92, de 11 de Abril, que regulava a fixação das taxas moderadoras, dizia-se: "são princípios de justiça social que impõem que pessoas com maiores rendimentos e que não são doentes crónicos ou de risco paguem parte da prestação dos cuidados de saúde de que sejam beneficiários, para que outros, mais carenciados e desprotegidos, nada tenham de pagar”. 
Da mesma forma, no mais recente Decreto-Lei $n^{0} 173 / 2003$, de $1^{\circ}$ de Agosto, o legislador, embora apenas no mesmo plano do discurso, vai ainda mais longe e configura as taxas moderadoras como meio adequado para "introduzir também um princípio de justiça social no próprio acesso" ao SNS. "Nesta sequência, impõe-se estabelecer um regime que seja capaz de servir de instrumento moderador, racionalizador e regulador do acesso à prestação de cuidados de saúde e que, simultaneamente, garanta o reforço efectivo do princípio de justiça social no Sistema Nacional de Saúde. Para alcançar estas finalidades, torna-se necessário proceder a uma dinamização deste instrumento de política de saúde, o que pressupõe um processo que evolua, futuramente, no sentido da redefinição da fixação dos valores das taxas, assente em critérios de proporcionalidade e adequação ao rendimento dos utentes”.

Ensaia-se aí, claramente, a entrada numa nova lógica, a do pagamento, por parte dos utentes, dos custos, pelo menos parcelares, de prestações obtidas no âmbito do SNS. Esta nova modalidade é, como vimos, comportada pelo actual quadro constitucional, mas reveste uma sensibilidade política que apela a uma aplicação cuidada dos limites constitucionais aplicáveis.

Vimos já que a exigência constitucional de um SNS tendencialmente gratuito permite, em circunstâncias ainda não analisadas, a imposição de alguma espécie de pagamento pelas prestações que os utentes obtêm no serviço nacional de saúde. Todavia, essa possibilidade está sujeita a limites constitucionais precisos.

Em primeiro lugar, essa possibilidade não pode obnubilar o tom geral e principal da norma constitucional e que é, precisamente, o de garantir um acesso aos cuidados de saúde prestados pelo SNS que, por tendência, deve ser gratuito. Ora, o sentido geral desta tendencial gratuitidade traduz-se em duas exigências já especificamente salientadas pelo Tribunal Constitucional. De um lado, a tendencial gratuitidade é garantida pelo facto de o SNS dever ser basicamente financiado pelo Orçamento do Estado. Por outro lado, significa que a nenhum particular pode ser vedado o acesso às prestações de saúde de que carece, no âmbito do SNS, por facto de se lhe fazerem exigências de pagamento que está objectivamente incapaz de satisfazer.

Em segundo lugar, a maior flexibilidade introduzida com a nova redacção (após a revisão constitucional de 1989) da norma constitucional não pode significar uma afectação desvantajosa do acesso gratuito hoje já garantido aos grupos e categorias isentos do pagamento de taxas moderadoras. Desde que os fundamentos que conduziram a essa isenção respeitem a exigências de justiça social ligadas à razão anterior —ou seja, a garantia constitucional de que a ninguém seja vedado o acesso aos cuidados de saúde por razões económicas-, não há razões que justifiquem, nesses casos, a referida maior flexibilidade, pelo que as actuais isenções devem beneficiar, em geral, da mesma garantia de que beneficiavam relativamente às taxas moderadoras.

Em terceiro lugar, a possibilidade de instituição de um pagamento, pelo menos parcelar, de custos de prestação de cuidados de saúde no âmbito do SNS não é incondicionada. Ela está, como se disse, vinculada à observância dos princípios constitucionais estruturantes e, desde logo, do princípio da proibição do excesso e do princípio da igualdade. 
Não ser excessiva significa a observância das várias dimensões desse princípio: a aptidão, a indispensabilidade, a proporcionalidade e a razoabilidade ${ }^{27}$, que, no seu conjunto, significam essencialmente que, tendo em conta a situação particular de cada cidadão, não se lhe pode exigir como pagamento mais do que aquilo que, atendendo à respectiva situação económica e social, ele pode razoavelmente pagar sem pôr em causa um acesso adequado aos cuidados de saúde.

Por último, e associada a esta garantia de proibição do excesso, vem a exigência de um tratamento materialmente igual para todos os cidadãos. Assim, para além da garantia de um acesso não economicamente condicionado e da proibição do excesso, é ainda garantida a igualdade na distribuição dos encargos exigidos aos cidadãos. Sendo um princípio de aplicação geral em Estado de Direito, a Constituição preocupou-se, neste caso concreto, a conferir uma formulação particularmente concretizada ao princípio da igualdade para efeitos de pagamentos das prestações no âmbito do SNS.

Permitindo, com os condicionamentos já assinalados, alguma espécie ou modalidade de pagamento dos cuidados de saúde, a Constituição fixou desde logo os critérios gerais que presidem à respectiva fixação. E esses critérios são os da condição económica e social dos utentes do SNS.

Assim, a determinação dos contornos concretos da tendencial gratuitidade cabe ao legislador democrático, mas essa graduação é vinculada pelos critérios já constitucionalmente pré-estabelecidos: tanto a determinação das isenções (gratuitidade integral para os grupos mais carenciados) quanto a fixação do montante do eventual pagamento depende essencialmente das capacidades económicas e condição social do utente.

\section{REFERÊNCIAS}

ANDRADE, José Carlos Vieira de. “O ‘direito ao mínimo de existência condigna’ como direito fundamental a prestações estaduais positivas —uma decisão singular do Tribunal Constitucional”. Jurisprudência Constitucional, 1.

BARROS, Pedro P. e NUNES, Pedro. A sustentabilidade financeira do Serviço Nacional de Saúde. Universidade Nova de Lisboa, 2005.

CAMPOS, Correia de e RAMOS, Francisco. Contas e ganhos na saúde em Portugal. Dez anos de percurso. Desafios para Portugal, Lisboa, 2005.

CANOTILHO, J. J. Gomes e MOREIRA, Vital. Constituição da República Portuguesa Anotada, 3. ed., Coimbra, 2007.

CANOTILHO, J. J. Gomes. Anotação ao Acórdão $n^{\circ}$ 148/94. Revista de Legislação e Jurisprudência, 3841, 3842.

CANOTILHO, J. J. Gomes. Tribunal Constitucional, Jurisprudências e Políticas Públicas, Palestra proferida na Conferência no XX Aniversário do Tribunal Constitucional, Lisboa, 2003.

CORREIA, Sérvulo. As relações jurídicas de prestação de cuidados pelas unidades de saúde do Serviço Nacional de Saúde. Direito da Saúde e Bioética, Lisboa, 1996.

GOUVEIA, Jorge Bacelar. A inconstitucionalidade da lei das propinas. Revista da Faculdade de Direito da Universidade de Lisboa, 1995.

${ }^{27}$ Cf. JORGE REIS NOVAIS, Os Princípios Constitucionais Estruturantes..., cit., págs. 161 e segs.. 
MIRANDA, Jorge e GARCIA, Maria da Glória. A lei de financiamento do ensino superior. Revista da Faculdade de Direito da Universidade de Lisboa, 1998.

MIRANDA, Jorge e MEDEIROS, Rui. Constituição Portuguesa Anotada, I, Coimbra, 2005.

MIRANDA, Jorge. "Pensões no sector bancário e direito à segurança social (parecer)". Jurisprudência Constitucional, 7.

MIRANDA, Jorge. Manual de Direito Constitucional, t. IV, Coimbra, 2008.

NOVAIS, Jorge Reis. As Restrições aos Direitos Fundamentais não Expressamente Autorizadas pela Constituição, Coimbra, 2003.

NOVAIS, Jorge Reis. Direitos Fundamentais: Trunfos contra a Maioria, Coimbra, 2006.

NOVAIS, Jorge Reis. Direitos Sociais, Coimbra, 2010.

NOVAIS, Jorge Reis. Os Princípios Constitucionais Estruturantes da República Portuguesa, Coimbra, 2004.

SIMÕES, Jorge. Retrato Político da Saúde, Coimbra, 2004.

VALE, Luís Meneses. A jurisprudência do Tribunal Constitucional sobre o acesso às prestações concretizadoras do direito à protecção da saúde: alguns momentos fundamentais. Jurisprudência Constitucional, 12, 2006. 